\title{
Short Chain Fatty Acid
}

National Cancer Institute

\section{Source}

National Cancer Institute. Short Chain Fatty Acid. NCI Thesaurus. Code C68424.

A class of dietary fatty acids that have an alkyl chain leng th from 2 up to 5 carbon atoms. 